Florida A\&M University College of Law Scholarly Commons@ FAMU Law

Library Faculty Publications

Law Library

4-7-2015

\title{
Wanting to Do More But Bound to Do Less: A Law Librarian's Dilemma
}

Paul Jerome McLaughlin Jr.

Florida AぬM University College of Law, paul.mclaughlin@famu.edu

Follow this and additional works at: http://commons.law.famu.edu/library-facpub

Part of the Legal Education Commons, Legal Ethics and Professional Responsibility Commons, and the Library and Information Science Commons

\section{Recommended Citation}

Paul Jerome McLaughlin Jr. (2015) Wanting to Do More But Bound to Do Less: A Law Librarian's Dilemma, The Reference Librarian, 56:2, 119-132, DOI: $10.1080 / 02763877.2014 .982316$

This Article is brought to you for free and open access by the Law Library at Scholarly Commons @ FAMU Law. It has been accepted for inclusion in Library Faculty Publications by an authorized administrator of Scholarly Commons @ FAMU Law. For more information, please contact linda.barrette@famu.edu. 


\title{
Wanting to Do More But Bound to Do Less: A Law Librarian's Dilemma
}

\author{
PAUL JEROME MCLAUGHLIN, JR. \\ Florida Agricultural and Mechanical University, Orlando, FL
}

\begin{abstract}
The role of the law librarian has changed from managing the contents of a library's collection of books to knowing bow to find information sources located around the world contained in a variety of formats, taking part in instruction, and participating in networking activities. Law librarians are constrained by legal and professional codes. If they are cautious, law librarians can assist, instruct, and reach out to public patrons and students while operating within the professional guidelines that govern them.
\end{abstract}

KEYWORDS ethics, law librarians, outreach reference services, public patrons, social media, teaching, unauthorized practice of law

As law schools' teaching methods and the librarian position itself come under scrutiny, it is vital for law librarians to make the most out of every opportunity and tool. When academic law libraries were first founded, law librarians had to locate information kept in a relatively small set of books and infrequently published judicial opinions (Ahlers, 2002). Now, law librarians must retrieve legal and interdisciplinary information for patrons in print, digital, microfiche, and many other formats (Ahlers, 2002). Beyond finding information for patrons, because of the complexity and constantly changing tools used in conducting legal research, law librarians are becoming more involved in teaching skill-based courses that focus on preparing students to practice (Lenz, 2013). Most reference librarians have done well in adapting to the changes in the educational and reference worlds because of their flexibility and creativity when they implement solutions for the challenges

(C) Paul Jerome McLaughlin, Jr.

Address correspondence to Paul Jerome McLaughlin, Jr., College of Law, Florida Agricultural and Mechanical University, 201 Beggs Avenue, Orlando, FL 32801. E-mail: paul. mclaughlin@famu.edu 
they face. Instead of waiting for patrons and students to come to them, reference librarians use tools such as online guides, social media, and their libraries' websites to reach out to and educate library users as to what is available through their libraries and how to access it (Hope, Kajiwara, \& Liu, 2001).

Law librarians, however, face a unique set of constraints and conflicting directives when trying to provide information to patrons and students that librarians at other academic libraries do not. Law librarians have professional rules and ethical codes placed on them by the American Association of Law Libraries (AALL), the American Bar Association (ABA), the American Library Association (ALA), and the laws of the states where their libraries are located (Garner, 1992). Of particular concern to law librarians are the rules and laws that prohibit the unauthorized practice of law. Even when reaching out to patrons and students through social media, law librarians have to be cautious because of the possibility of violating ethical and professional codes of conduct (Harari, 2012).

\section{A HISTORY OF LAW LIBRARIES AND THE ROLE OF THE LAW LIBRARIAN}

\section{The Evolution of the Law Library's Collection}

Early law libraries began as small collections of sporadically released judicial opinions and published laws kept by the legal experts who depended on them (Whiteman, 2014). As the proliferation of opinions, treatises, government publications, and other legal materials grew, so did the libraries that housed them (Roalfe, 1953). Because of the increase in volume of published legal documents, classification systems and subject headings for legal materials were created to help organize the information through joint efforts between organizations such as the AALL and skilled individuals such as A. J. Small (Murley, 2007). As shelf space became a premium in law libraries, alternative means of keeping information, such as microforms, were used to save space (Ahlers, 2002). Legal information of all kinds can now be accessed electronically on the Internet through providers such as Lexis and Westlaw, which has allowed libraries to save physical space but has put libraries in the position of licensing access to rather that owning the sources they depend on (Ahlers, 2002).

\section{Changes in the Law Librarian's Role}

As academic legal libraries' collections grew and became more complex, professional librarians were required to maintain, organize, and help patrons access the materials (Price, 1948). Law librarians became an indispensable 
part of the law library because of their knowledge of their libraries' collections and their skill in locating the materials people sought (Kenyon, 1965). As legal research evolved to require the use of more intricate methods and wider arrays of sources, law librarians began to teach both students and legal professionals how to conduct effective research using current methods and tools (Janto \& Harrison-Cox, 1992). Law librarians now use a variety of print and electronic resources to find information, teach legal information retrieval skills, and reach out to faculty, patrons, students, and fellow legal experts around the world (Germain, 2007).

\section{THE DILEMMAS THAT LAW LIBRARIANS FACE}

\section{Conflicting Mandates When Assisting Public Patrons}

The number of individuals who choose to enter the court system pro se (without the aid of an attorney) is on the rise (Landsmen, 2012). Pro se litigants often visit local libraries to find information that will help them prepare their cases (Healey, 2002). When asked by members of the public to assist them in finding legal information, law librarians find themselves in an uncomfortable position, given their status as both librarians and legal professionals. Law librarians are compelled to help their library's users, but because of the array of professional guidelines, codes, and laws prohibiting the unauthorized practice of law it can be difficult for them to determine what assistance they can provide (Garner, 1992).

Law librarians are directed by the AALL's Ethical Principles to render aid to nonlawyers in finding legal information (American Association of Law Libraries, 1999). The AALL encourages law librarians to teach users of the library how to find legal information efficiently and cost-effectively as part of its Competencies of Law Librarianship (AALL, 2010). Under the ALA's guidelines, law librarians are to provide complete and accurate reference services when assisting a patron, which can require that law librarians ask clarifying questions to determine the information that patrons need (ALA, 2013).

Balanced against the requirements for law librarians to help and teach members of the public are sets of professional codes and laws that prohibit librarians from giving legal advice. The AALL's Ethical Principles state that law librarians should avoid the unauthorized practice of law while rendering services to people (AALL, 1999). For law librarians who hold law licenses, the issue of what they can and should do while helping members of the public is even more complex. Under the ABA's Model Rules, lawyers are encouraged to provide pro bono services to those who cannot afford legal representation (ABA, 2013). While providing legal services to members of the public seeking legal information would seem to be a natural fit for law librarians who are licensed attorneys, the AALL's Ethical Principles require 
that librarians not engage in the practice of law while providing reference services (Garner, 1992).

Unfortunately, legal authority does not define with specificity what constitutes engaging in the practice of law (Healey, 1998). Without a firm definition of what is considered the practice of law, it is possible that conducting a reference interview or providing the most basic of reference assistance to a patron could be considered committing the unauthorized practice of law (Healey, 1998). If law librarians engage in the unauthorized practice of law, they could face not only criminal charges but also claims for damages from the people they assist if their case does not succeed (Abrams \& Dunn, 1978). While there has never been a reported claim against a librarian for malpractice or a librarian being charged with the unauthorized practice of law for providing reference services to a public patron, there is still the possibility of such an event occurring (Healey, 2014). Even if law librarians hold a law license, they are encouraged not to help people prepare their cases or make legal determinations to reduce the possibility of a patron making a claim against them for malpractice and to avoid potential ethical and professional issues (Leone, 1980).

\section{Potential Issues When Law Librarians Use Social Media}

\section{Concerns With Using Social Media and Public Patrons}

Law librarians must keep the content of their posts on social media as general and free of legal information as possible. Librarians who make social media posts that discuss legal issues and subjects could be seen as committing the unauthorized practice of law (Lackey \& Minta, 2012). Law librarians who hold law licenses must be judicious when making social media posts so they do not give the appearance of forming an attorney-client relationship with a patron (Lackey \& Minta, 2012). Under the AALL's Ethical Principles, law librarians have the responsibility to keep patrons' information confidential (1999). The task of keeping patrons' information from public access can be difficult when patrons give details about the situation they face and what they are searching for in their posts (Parry, 2012).

\section{Issues Associated With Using Social Media to Reach Out to STUDENTS}

A quick and effective way for librarians to reach out to students is by using social media (Carlson, 2007). However, for law librarians and law students both, the use of social media is not without potential pitfalls. Law librarians' and students' social media posts can come under scrutiny from their state's bar ethics enforcement agents (DiBianca, 2011). There has never been a case that clearly establishes when website content is considered public or private, 
even if the author of the content meant for the information to be viewed by a select group of people (Pabarcus, 2011). This lack of demarcation between public and private information on the Internet means that character and fitness boards could examine any post made by a student despite the student setting privacy settings to the maximum (Roedger, 2010). Student posts could also have an impact on their ability to gain a position if an employer chooses to scrutinize the student's online activities before making a hiring decision (Harari, 2012). There have even been cases of law students being reprimanded or dismissed by their school's administration because of their online posts (Belle, 2012).

\section{WHY IT IS IMPORTANT FOR LAW LIBRARIANS TO OVERCOME THESE CHALLENGES}

Assisting Public Patrons Does More Than Help an Individual

The Supreme Court in Faretta v. California (1975) established the right of an individual to enter into the court system without the aid of an attorney. Since then, the number of pro se litigants entering the court system has increased substantially, particularly in the area of domestic relations (Landsman, 2012). Having a larger number of pro se litigants enter into the court system has the potential to slow down the already struggling courts as they allocate more time and resources helping pro se clients advance their case (Landsman, 2012). In Pliler v. Ford (2004) the Supreme Court held that judges do not have to provide special help to pro se litigants and that assisting them in the trial process would make it appear that the judges were not impartial during proceedings. Law librarians can help the courts by providing reference services to pro se litigants, which frees up court staff to tend to other vital functions instead of trying to handle litigants' questions about the law (Fitzgerald, 2003). For the libraries that enable law librarians to provide public reference services, there is the possibility of more funding becoming available as the legal community recognizes the aid that libraries lend to the court system (Fitzgerald, 2003).

\section{Social Media Is Pivotal for Modern Reference Services and Teaching}

The traditional way that law schools educate their students has come under criticism from many sources and law schools have begun to adapt their teaching methods to better meet the needs of their students and the legal profession (Spencer, 2012). Law librarians can be critical in overcoming the disassociation between law school education and the realities of legal practice if they are active in teaching students how to frame their research questions and what materials they should use (Sadow \& Beede, 1975). 
Undergraduate students tend to use electronic formats to search for information and this tendency continues through the time they are law students (Keefe, 2005). A study conducted by Jones (2006) found that students in a farm worker legal aid clinic used online resources and consulted legal experts directly or through online means, such as electronic mailing lists, far more often than they used their library's resources. Students' reliance on online searches for information can create a "gap" between them and law librarians who rely primarily on print sources to teach legal research methods (Keefe, 2005, p. 124).

Law librarians can close the educational distance between them and their students by using social media in their teaching. Butler (2012) encouraged the use of resource-based teaching methods to introduce students to the legal research process. Resource-based teaching methods tend to foster practical skills, focus on online research tools, and have the propensity to develop metacognative research approaches in students (Butler, 2012). An important aspect of the resource-based teaching method is the use of electronic communication tools to connect with students and provide a more varied learning environment (Butler, 2012). An example of electronic communication being used in a law school class setting to good effect is the iSection created by the New York School of Law which utilizes a number of electronic tools, including social media, to help students learn and give them experience working on collaborative group projects (Broussard, 2008).

\section{Students Must Be Aware of How to Use Social Media Responsibly}

As students become legal professionals, they face another set of set of pressures and responsibilities when using social media. While there is no formal requirement for competency regarding social media usage and lawyers, DiBianca (2011) recommended that all legal professionals become familiar with social media enough to know the possible ethical and legal ramifications that its use can have on them and their practice. Attorneys can use social media as a way to advertise, but they must be aware of their jurisdiction's rules about what they are allowed to post concerning their practice and whether or not they have to have a disclaimer along with the advertisement (Seidenberg, 2011). Attorneys using social media have to be aware that there is the possibility of creating an attorney client relationship if certain kinds of information are shared by individuals seeking legal guidance (Bennett, 2009). Attorneys are encouraged to search social media posts for evidence that could bolster their case, such as statements made online that could impeach a witness' in court testimony as part of their due diligence requirement for preparing a case (Browning, 2010). Attorneys have the duty to keep the communications between them and their clients confidential and to maintain the protection of the attorney client privilege, which can be difficult to do if social media are the means of communication used (Bennett, 
2009). Clients have to be informed concerning what kinds of details about their case they should refrain from posting online so they do not inadvertently dissolve the attorney client privilege and allow the opposing party to have information that would be damaging to their case (O'Brian, 2009). Attorneys must instruct employees on the proper use of social media to prevent privileged information from being published online as part of their duty of supervision (O'Brien, 2009).

If they advance far enough in their careers and become judges, students must be aware that there are specialized rules that govern what they can and cannot do do while using social media that are broader than even those that cover attorneys. There are jurisdictions that do not allow judges to be "friends" with, "follow," or recommend attorneys who may appear before them on social media to avoid giving the impression that those attorneys have an advantage in their court (Lackey \& Minta, 2012, p. 168). If judges discuss details of a case with attorneys using social media it can be construed as a form of ex parte communication, which is prohibited by the ABA's rules of conduct (O'Brian, 2010). Judges have to be aware of the potential misuse of social media by jurors during trials and take steps to ensure the integrity of their court's proceedings. Jurors must be instructed not to post descriptions of events or testimony on social media, or search social media for outside information on the trial they are involved with to help ensure that the parties involved receive a fair trial (St. Eve, 2012).

\section{Social Media Is a Vital Tool for Outreach}

Given the ongoing changes in the legal education and library fields, law libraries cannot remain isolated and must reach out to others to share resources and knowledge (Palfrey, 2010). Using social media as an outreach tool allows law librarians to accomplish several goals. The AALL's Competencies require that law librarians create and maintain online resources and participate in networking and online communities (AALL, 2010). Using social media allows law librarians to make global connections with specialists who can help them find both legal and nonlegal information (Germain, 2007).

The use of social media allows librarians to engage patrons by "going where they are" virtually using online sites that students are already involved with (Carlson, 2007, p. 27). Law libraries can use social media as a cost effective means to reach out to patrons through a variety of forums such as blogs, online messaging, Facebook pages, Twitter, and wikis (Shrager, 2010). Law school libraries, such as Harvard's and Duke's, have used Facebook pages to communicate with and gather feedback from their students and patrons with good success (Behrens, 2008). By seeking the input of students, faculty, and other library users, law librarians put the library in the minds of its intended patrons and gain valuable feedback about what should be 
in its collection (Kenyon, 1965). Knowing what patrons need and use in the library is particularly important during difficult financial times so that a library's collection can be maintained as cost-efficiently as possible (Fitchett, Hambleton, Hazelton, Klinefelter, \& Wright, 2011).

\section{POSSIBLE SOLUTIONS TO THE DILEMMAS}

Public patrons and law students often require assistance in finding the legal information they need. If law librarians are mindful about their tools and methods, they can provide guidance to patrons and students alike without transgressing ethical or legal boundaries.

\section{Library Websites and Online Guides}

Patrons of all kinds, and from all over the world, use law library websites in order to find the legal information they need (Thorpe, 2002). Most law libraries allow online patrons to access their catalog through their website, but law library websites can also be designed to act as portals to specialized information for public patrons and students such as online research guides (Sims, 2004). Online guides can be of particular help for patrons who are looking for books, forms, and contact information to legal services when they are not familiar with legal sources and their organizational systems (Sims, 2004). Using online guides, law librarians can provide public patrons with legal information without the ethical and professional risks that conducting in person reference sessions entail (Condon, 2001).

One way that law librarians can create dynamic and user-friendly online guides is by constructing LibGuides (online research guides hosted by Springshare) provide overviews of topics and listings of links to sources that can be useful for patrons (Springshare, 2014). Typically, librarians create LibGuides to cover a particular course or subject that students are studying and to provide information about the materials available in their library that cover that subject (Cofield \& Solon, 2012). By creating LibGuides, or any other form of online guide, law librarians help their libraries meet the AALL's competency requirements of having an online presence, making information available to nonlawyers, creating bibliographic tools, and creating customized teaching tools (Todd, 2007).

\section{Assisting and Instructing Public Patrons}

Public patrons are often not skilled in looking for legal materials, do not know the specifics of the information that they need, and can take up a good portion of a law librarian's time while searching for information (Begg, 
1976). Librarians have adopted several different approaches when interacting with public patrons that range from helping as much as possible to excluding public patrons from reference services altogether (Healey, 1998).

Brown (1994) suggested that librarians help patrons find the information they need through indexes and digests but that the patrons themselves should make any determinations about their legal situation and the information that they find. Protti (1991) argued that while providing even basic reference services to public patrons does entail making legal determinations, that law librarians should do all that they can, including interpreting the law and giving legal advice, to help patrons find the information that they need to prepare their cases. Mosley (1995) took a different stance on the public patron dilemma and wrote that the reference services that librarians provide are clearly distinguishable from the practice of law. He advocated that librarians help patrons collect the information that they need, including providing specific citations, but that they should avoid providing lawyerly services such as completing or filing documents, predicting outcomes of legal arguments, or advising what procedural steps to take (Mosley, 1995).

Although there is no consensus on what the limits are for librarians when helping patrons find legal information, caution and preparation are necessary to minimize the chance of legal and ethical problems (Healey, 2002). Law librarians who wish to limit the risk of crossing their professional boundaries should avoid asking detailed reference questions and refrain from giving explanations to legal terms or concepts (Schanck, 1979). Posted and verbal disclaimers about what law librarians can and cannot do can help patrons understand before a reference session begins that there are limits to what a librarian is permitted to do when providing reference services (Brown, 1994).

Printed handouts about the legal research process and topically focused pathfinders can be of service to both patrons and librarians (Healey, 2014). Handouts can provide guidance and bibliographic explanations for patrons unfamiliar with researching legal topics and can have a disclaimer placed in them about what librarians can do and not do when helping find legal information (Arant \& Carpenter, 1999).

\section{Helping and Teaching Students in Person}

When helping students find information, law librarians are not as constrained as when they assist public patrons. However, in place of the various ethical and legal issues that come with helping public patrons, law librarians have the duty to ensure that the students they assist not only find the information that they are looking for but also gain a deeper understanding of the legal research process (Arrigo, 2001). While helping students, law librarians must balance directing students to the information that they need before they 
become frustrated against the value of letting students go through the process themselves so they develop their own legal research skills (Arrigo, 2001).

Butler (2012) advocated using problem-based teaching methods in law schools. Problem-based teaching methods focus on developing students' knowledge and critical thinking by having students solve problems rather than learning through lectures (Butler, 2012). Woxland (1989) wrote that law librarians can have a positive impact on students who come to them for assistance since the students have "real research problems" that law librarians can use as a base for teaching legal research methods and bibliography (p. 463). Adult learners, such as law students, tend to have more success in learning new concepts when they use skills and knowledge that they have already developed to complete a task and see how the information they are learning can be applied in a practical situation (Sonsteng, Ward, Bruce, \& Petersen, 2007). While providing guidance and instruction during a reference session, law librarians can help students recognize that they will be serving clients with multilayered legal problems and not answering the kinds of hypothetical questions that they have been introduced to in the classroom, a distinction that Moskovitz (1992) felt that is vital for students to understand before they enter the legal profession.

\section{Leveraging Social Media As a Teaching Tool}

Because of the wide availability of information through the Internet, legal authority has expanded and students must become familiar with searching for information in variety of specialized fields (Margolis, 2011). Class projects that center on the use of social media can be used to teach interdisciplinary research, foster collaborative skills, and serve as an example of how to use social media responsibly (Hoorn \& van Hoorn, 2007). In 2007, the University of Western Australia School of Law created a Comparative Law Wikipedia article as a part of its comparative law elective course's exercises (Witzleb, 2009). The creation of the Wikipedia article provided a well-researched guide in comparative law for anyone to access, gave the students an opportunity to learn and apply practical legal research skills, and put the law school's name out in a positive way (Witzleb, 2009).

As a practical exercise to expose students to the potential downsides of posting on social media, law librarians can have students run searches on themselves. Keller and the American Bar Association Young Lawyers Division (2011) recommended that anyone involved in the legal field should conduct a name search using Google.com, Bing.com, Pipl.com, and search.Intelius.com to monitor their online presence. Once students search for information about themselves and realize how easy it is for others to find information about them and their online activities, they may change their social networking habits and take a more active role in maintaining their online image (Vinson, 2010). 


\section{CONCLUSION}

Although law librarians are not as free to adapt as other librarians are, it does not mean that they must remain static to adhere to the ethical and professional rules that they operate under. Law librarians can use this transitional time in the legal education curriculum to demonstrate that they have the knowledge and teaching methods needed to assist in making legal education more practical and understandable for law students. They can also show the judicial, social, and possibly financial merits of helping public patrons find the legal information that they need. If law librarians are innovative, flexible, and prudent in how they overcome the challenges facing them they can be instrumental in the shaping of their profession's future as both educators and providers of legal assistance.

\section{REFERENCES}

Abrams, R. H., \& Dunn, D. J. (1978). Law library's institutional response to the pro se patron: A post-faretta review. Western New England Law Review, 1, 47-67.

Ahlers, G. (2002). The history of law school libraries in the United States: From laboratory to cyberspace. Buffalo, NY: William S. Hein \& Company.

American Association of Law Libraries. (1999). AALL ethical principles. Retrieved from http://www.aallnet.org/main-menu/Leadership-Governance/ policies/PublicPolicies/policy-ethics.html

American Association of Law Libraries. (2010). Competencies of law librarianship. Retrieved from http://www.aallnet.org/main-menu/Leadership-Governance/ policies/PublicPolicies/competencies.html

American Bar Association. (2013). Model rules of professional conduct. Retrieved from http://www.americanbar.org/groups/professional_ responsibility/publications/model_rules_of_professional_conduct/model_rules_ of_professional_conduct_table_of_contents.html

American Library Association. (2013). Guidelines for behavioral performance of reference and information service providers. Retrieved from http://www.ala.org/ rusa/resources/guidelines/guidelinesbehavioral

Arant, W., \& Carpenter, B. (1999). Where is the line? Legal reference service and the unauthorized practice of law (UPL) - Some guides that might help. Reference $\varepsilon$ User Services Quarterly, 38(3), 235-239.

Arrigo, P. A. (2001). Taking time for legal research instruction at the reference desk. Legal Reference Services Quarterly, 19, 75-98.

Begg, R. T. (1976). Reference librarian and the pro se patron. Law Library Journal, 69, 26-32.

Behrens, J. L. (2007). About Facebook-Change at the social-networking juggernaut creates new opportunities for law library outreach. AALL Spectrum, 12, 14-17.

Belle, J. (2012). Social media policies for character and fitness evaluations. Washington Journal of Law, Technology and Arts, 8, 107-122. 
Bennett, S. C. (2009). Ethics of lawyer social networking. Albany Law Review, 73, $113-137$.

Broussard, C. (2008). Teaching with technology: Is the pedagogical fulcrum shifting? New York School Law Review, 53, 903-915.

Brown, Y. (1994). From the reference desk to the jail house: Unauthorized practice of law and librarians. Legal Reference Services Quarterly, 13, 31-45.

Browning, J. G. (2010). Digging for the digital dirt: Discovery and use of evidence from social media sites. SMU Science and Technology Law Review, 14, 465-496.

Butler, M. (2012). Resource-based learning and course design: A brief theoretical overview and practical suggestions. Law Library Journal, 104, 219-244.

Carlson, S. (2007). Are reference desks dying out? Librarians struggle to redefine-and in some cases eliminate-the venerable institution. The Reference Librarian, 48 , $25-30$.

Cofield, M., \& Solon, K. (2012). Making the most of LibGuides in law libraries: How can law libraries leverage LibGuides? AALL Spectrum, 16, 17-18.

Condon, C. J. (2001). How to avoid the unauthorized practice of law at the reference desk. Legal Reference Services Quarterly, 19, 165-179.

DiBianca, M. M. (2011). Ethical risks arising from lawyers' use of (and refusal to use) social media. Delaware Law Review, 12, 179-199.

Faretta v. California, 422 U.S. 806 (1975).

Fitchett, T., Hambleton, J., Hazelton, P., Klinefelter, A., \& Wright, J. (2011). Law library budgets in hard times. Law Library Journal, 103, 91-111.

Fitzgerald, K. L. (2003). Serving pro se patrons: An obligation and an opportunity. Legal Reference Services Quarterly, 22, 41-73.

Garner, K. (1992). Lawyer-librarians in public law schools: The ethical conundrums of pro bono activities. Law Library Journal, 84, 31-66.

Germain, C. (2007). Legal information management in a global and digital age: Revolution and tradition. International Journal of Legal Information, 35, $134-163$.

Harari, T. (2012). Facebook frenzy around the world: The different implications Facebook has on law students, lawyers, and judges. ILSA Journal of International and Comparative Law, 19, 1-30.

Healey, P. D. (1998). In search of the delicate balance: Legal and ethical questions in assisting the pro se patron. Law Library Journal, 90, 129-148.

Healey, P. D. (2002). Pro se users, reference liability, and the unauthorized practice of law: Twenty-five selected readings. Law Library Journal, 94, 133-139.

Healey, P. D. (2014). Legal reference for librarians: How and where to find the answers. Chicago, IL: ALA Editions, American Library Association.

Hoorn, E., \& van Hoorn, D. (2007). Critical assessment of using wikis in legal education. Journal of Information, Law and Technology, 2007(1), 28-37.

Hope, C. B., Kajiwara, S., \& Liu, M. (2001). The impact of the internet: Increasing the reference librarian's role as teacher. The Reference Librarian, 35, 13-36.

Janto, J. M., \& Harrison-Cox, L. D. (1992). Teaching legal research: Past and present. Law Library Journal, 84, 281-297.

Jones, Y. P. (2006). Just the facts ma'am?: A contextual approach to the legal information use environment. In J. M. Carroll (Ed.), Proceedings of the Gth Conference on Designing Interactive Systems (pp. 357-359). New York, NY: ACM. 
Keefe, T. (2005). Teaching legal research from the inside out. Law Library Journal, 97, 117-131.

Keller, D. K., \& American Bar Association Young Lawyers Division. (2011). The associate as rainmaker: Building your business brain. Chicago, IL: American Bar Association.

Kenyon, C. W. (1965). Mission of the legal reference librarian. Law Library Journal, $58,123-129$.

Lackey, M. E., Jr. \& Minta, J. P. (2012). Lawyers and social media: The legal ethics of tweeting, Facebooking and blogging. Touro Law Review, 28, 149-182.

Landsman, S. (2012). Pro se litigation. Annual Review of Law and Social Science, 8, 231-253.

Lenz, C. (2013). The public mission of the public law school library. Law Library Journal, 105, 31-55.

Leone, G. (1980). Malpractice liability of a law librarian. Law Library Journal, 73, 44-65.

Margolis, E. (2011). Authority without borders: The world wide web and the delegalization of law. Seton Hall Law Review, 41, 909-945.

Moskovitz, M. (1992). Beyond the case method: It's time to teach with problems. Journal of Legal Education, 42, 241-270.

Mosley, Jr., M. (1995). Authorized Practice of Legal Reference Service, The. Law Library Journal, 87, 203-209.

Murley, D. (2007). What is all the fuss about library 2.0. Law Library Journal, 100, 197-204.

O'Brien, A. (2009). Are attorneys and judges one tweet, blog or friend request away from facing a disciplinary committee? Loyola Journal of Public Interest Law, 11, $511-540$.

Pabarcus, A. (2011). Are private spaces on social networking websites truly privatethe extension of intrusion upon seclusion. William Mitchell Law Review, 38, $397-432$.

Palfrey, J. (2010). Cornerstones of law libraries for an era of digital-plus. Law Library Journal, 102, 171-190.

Parry, M. (2012, November). As libraries go digital, sharing of data is at odds with tradition of privacy. Chronicle of Higher Education. Retrieved from http:// chronicle.com/article/As-Libraries-Go-Digital/135514/

Pliler v. Ford, 542 U.S. 225 (2004).

Price, M. O. (1948). Law school librarian. Journal of Legal Education, 1, 268-271.

Protti, M. E. (1991). Dispensing law at the front lines: Ethical dilemmas in law librarianship. Library Trends, 40, 234-243.

Roalfe, W. R. (1953). The libraries of the legal profession. St. Paul, MN: West Publishing Company.

Roedger, A. (2010). Wall posts, status updates, and the bar: How social networking impacts character and fitness requirements. Journal of the Legal Profession, 35, $145-156$.

Sadow, S., \& Beede, B. R. (1975). Library Instruction in American Law Schools. Law Library Journal, 68, 27-32.

Schanck, P. C. (1979). Unauthorized practice of law and the legal reference librarian. Law Library Journal, 72, 57-64. 
Seidenberg, S. (2011). Seduced: For lawyers, the appeal of social media is obviousit's also dangerous. ABA Journal, 97, 49-53.

Shrager, D. E. (2010). Moving past Web 2.0 b! An exploratory study of academic law libraries. Retrieved from http://works.bepress.com/aallcallforpapers/66

Sims, L. (2004). Academic law library web sites: A source of service to the pro se user. Legal Reference Services Quarterly, 23, 1-28.

Sonsteng, J. O., Ward, D., Bruce, C., \& Petersen, M. (2007). Legal education renaissance: A practical approach for the twenty-first century. William Mitchell Law Review, 34, 303-472.

Spencer, A. B. (2012). Law school critique in historical perspective. Washington $\&$ Lee Law Review, 69, 1949-2063.

Springshare. (2014). Libguides. Retrieved from http://www.springshare.com/ libguides/

St. Eve, A. J., \& Zuckerman, M. A. (2012). Ensuring an impartial jury in the age of social media.Duke Law \& Technology Review, 11, 1-29.

Thorpe, S. (2002). Trends in law library public services: Have you seen your patrons lately? AALL Spectrum, 6, 6-11.

Todd, K. M. (2007). Competencies of law librarianship: reference, research, and patron services. Legal Reference Services Quarterly, 26, 7-22.

Vinson, K. E. (2010). Blurred boundaries of social networking in the legal field: just face it. University of Memphis Law Review, 41, 355-412.

Whiteman, M. (2014). Book burning in the twenty-first century: ABA standard 606 and the future of academic law libraries as the smoke clears. Law Library Journal, 106, 11-46.

Witzleb, N. (2009). Engaging with the world: Students of comparative law write for Wikipedia. Legal Education Review, 19, 83-97.

Woxland, T. A. (1989). Why can't Johnny research-or it all started with Christopher Columbus Langdell. Law Library Journal, 81, 451-464. 